\title{
Recent patent applications in vectors
}

\begin{tabular}{|c|c|}
\hline Patent \# & \\
\hline WO 9829431 & $\begin{array}{l}\text { Thiazide sensitive cotransporter, ATP-sensitive K channel and co- } \\
\text { transporter genes; useful for developing products for the diagnosis } \\
\text { and treatment of ion transport disorders, e.g., Gitelman's Syndrome } \\
\text { or Bartter's Syndrome. }\end{array}$ \\
\hline WO 9829557 & $\begin{array}{l}\text { New ionic conjugate of particulate vector comprising hydrophilic } \\
\text { core and polyanionic oligonucleotide; useful for, e.g., inhibiting } \\
\text { gene expression in vitro or cell proliferation in vivo. }\end{array}$ \\
\hline WO 9829099 & $\begin{array}{l}\text { Mucosal administration of drugs, vaccines, etc., in biovector having } \\
\text { natural polymeric core; provides nonspecific targetting to mucosa, } \\
\text { good stability, controllable retention characteristics, and can be } \\
\text { loaded immediately before use. }\end{array}$ \\
\hline WO 9829102 & $\begin{array}{l}\text { New particulate vector with hydrophilic core and amphiphilic layer } \\
\text { with same charge as core; used to transport and deliver active } \\
\text { ingredients, e.g., proteins, nucleic acid, vaccines, etc., in } \\
\text { pharmaceutical or cosmetic compositions or as food additives. }\end{array}$ \\
\hline WO 9829533 & $\begin{array}{l}\text { Mutagenesis of mammalian genes using retroviral vectors comprising } \\
\text { a splice acceptor sequence, a transcription termination sequence, an } \\
\text { retroviral packaging and integration sequences. }\end{array}$ \\
\hline WO 9829554 & $\begin{array}{l}\text { Conferring resistance to herbicides that inhibit proto-porphyrinogen } \\
\text { oxidase by introducing DNA that encodes a resistant form of the } \\
\text { enzyme; also resistant plants and algae, mutant DNA, vectors, and } \\
\text { transformed microorganisms. }\end{array}$ \\
\hline WO 9829437 & $\begin{array}{l}\text { Newly isolated equilibrative nucleoside transporter protein(s) and } \\
\text { gene(s); used to develop products for treating disorder(s) associated } \\
\text { with the transporter(s) and for use with nucleoside drug(s). }\end{array}$ \\
\hline WO 9829441 & $\begin{array}{l}\text { New human galanin receptor, GALR2; useful for identifying agonists } \\
\text { and antagonists to treat conditions involving galanin, e.g., for } \\
\text { treatment of obesity or cognitive disorders. }\end{array}$ \\
\hline
\end{tabular}

WO 9829552 Serine-threonine kinase highly expressed in actively growing cells;

\begin{tabular}{|c|c|c|c|}
\hline Assignee & Author & Date & Status \\
\hline $\begin{array}{l}\text { Yale Univ. } \\
\text { (New Haven, CT) }\end{array}$ & Lifton RP, Simon DB & $7 / 9 / 98$ & A1 \\
\hline
\end{tabular}

Biovector

Therapeutics

(Labege, France)

Betbeder D, de Miguel $7 / 9 / 98$

I, Jarvis T, Kravtzoff

R, Pavco P, Sixou S

Biovector

Therapeutics

(Labege, France)

Betbeder D, de Miguel 7/9/98

I, Etienne A; Kravtzoff R,

Major M

Biovector

Therapeutics

(Labege, France)

Betbeder D, Major M 7/9/98
Sumitomo Chem. Co. Ltd. (Tokyo); Duke Univ.

(Durham, NC)

Univ. Alberta

(Edmonton, Canada); Univ. Leeds (UK)

Merck \& Co. Inc.

Whitehouse Sta., NJ);

$7 / 9 / 98$

Gillham NW, Ishige F,

Randolph-Anderson BL,

Sato R

Baldwin SA, Cass CE, $\quad 7 / 9 / 98$

Univ. Texas Health Sci. Sullivan K

Center (San Antonio, TX);

Univ. Toronto (Canada)

Chugai Res. Inst. Mol. Nezu J, Oku A

$7 / 9 / 98$

Bandman O,

$7 / 9 / 98$

WO 9829448 Human pathogenesis-related protein and related nucleic acids, trans- Incyte Pharm. formed cells, antibodies, and agonists; useful in treatment, prevention, (Palo Alto, CA) and diagnosis of cancer, infections, and neurological disease.

WO 9829432 Mycobacterium dihydrofolate reductase gene; useful for developing products for the prevention, diagnosis, and treatment of mycobacteria infections.

Southern Res. Inst.

(Birmingham, AL)

Barrow WW, Dooley

$7 / 9 / 98$

TP, Suling WJ,

van Ginkel SZ

$6 / 30 / 98$ with ubiquitin, and plants containing this vector stably integrated in Res. Found.

the genome; provides increased yields of proteins, e.g., pesticides or (Madison, WI)

Callis J, Hondr
Vierstra RD

Takara Shuzo Ltd.

Honke K

$6 / 30 / 98$ origin; useful for recombinant production of the enzyme and antisense control of the gene in vivo.

US 5773252 New isolated fibroblast growth factor-15; used to develop products for, e.g., stimulating revasularization, treating wounds, preventing neuronal damage, or treating tumors or hypervascular diseases.

US 5773250 New isolated polynucleotide encoding response regulator polypeptide; used to develop products for the diagnosis, prevention, and treatment of, e.g., otitis media, conjunctivitis, pneumonia, bacteria, meningitis, emphysema, or endocarditis.

US 5772993 Therapeutic agent for use in the treatment of tumors; comprises recombinant adenovirus vector containing osteocalin promoter for expression of toxic thymidine kinase.
(Shioga, Japan)

Human Genome

Greene JM, Rosen CA 6/30/98

Sciences

(Rockville, MD)

SmithKline Beecham

(London; Philadelphia,

$6 / 30 / 98$

A PA)

Univ. Virginia

Patent Found.

(Charlottesville, VA)
Chung LWK, Kao C, 6/30/98 Ko S, Sikes RA
Wallis NG

1

1

A

